E.L.U.A., 8, 1992, pp: 37-66

\title{
HACIA UN MODELO TEÓRICO QUE EXPLIQUE LA ESTRUCTURA SEMÁNTICA DE LOS SIGNIFICADOS EMOTIVOS
}

\author{
JUAN LUIS JimÉNEZ RUIZ \\ (Universidad de Alicante)
}

\begin{abstract}
RESUMEN
This essay, as its title shows, is intended to establish a theory of linguistics about connotative meaning within the context of dialectical analysis of meaning. Meaning is doubtless a complex phenomenon and, when trying to collect data about it, we have to move necessarily within different fields of study. Our essay shows the possible harmony that can exist between linguistic, semantic and symptomatic semantics. It is, first, a study on the different descriptions of denotative meaning. Symptomatic semantics is a study about the splanations of connotative meaning. We think that two perspectives cannot be considered to be opposite directions, but complementary proposals each of which achieves its reason to be in the dialectical model we defend. Here we present the second stage of this process: connotative meaning and the basis for the construction of a theoretical model able explain it within the dialectical framework we support.
\end{abstract}

Ya dejamos constancia anteriormente de que el significado es un elemento muy complejo cuya sistematización, descripción y explicación no corresponde sólo a la lingüística, sino que atañe a otras disciplinas'; puesto que, de hecho, aunque la descripción de los significados denotativos de las unidades que integran los campos léxicos permita el establecimiento del funcionamiento lingüístico del significado en el interior de un sistema léxico, la conclusión del

Nos referimos a una serie de trabajos en los que, por razones exclusivamente metodológicas, hemos intentado organizar las diferentes aportaciones que, desde ámbitos teóricos a veces muy distantes o dispares en apariencia, se han dado con el fin de abordar el apasionante y enigmático mundo del significado. Lejos del espíritu cientificista que obliga a la búsqueda de especificidad tanto en el objeto como en el método, una visión conjunta de las principales perspectivas de análisis semántico en un deseo de integración sintética enriquece los resultados finales y, lo que es más importante, abre nuevos horizontes dentro de la marcada ortodoxia de la lingüística actual; cf., entre otros, nuestros trabajos «Teoría», pp. 407-418; «Significados denotativos», pp. 61-97; «Descripción, explicación e interpretación», pp. $159-179$. 
análisis en este punto nos lleva al desconocimiento voluntario de múltiples facetas de los significados que una sola descripción empírica se ve insuficiente para abarcar; nos referimos a los aspectos emotivos no referenciales, a los significados connotativos que permiten al lenguaje hacerse poético y enmascarar dentro de sí significados que denotativamente no abarca.

Por ello, el estudio de la estructura semántica de los significados emotivos se hace necesario en el marco general de una semántica sintomática o explicativa que organice y traduzca a un lenguaje literal lo que desde una primera semántica de la referencia no se puede comprender ni abarcar. De ahí que, tras el primer acercamiento descriptivo, el análisis emotivo requiera una lectura no literal y la posterior traducción al lenguaje literal de esos significados de dudosa comprensión ${ }^{2}$.

Por todo lo anterior queda pues precisado y, lo más importante, justificado el objeto del presente trabajo; a saber, la revisión de algunas de las principales aportaciones que sobre el problema del significado connotativo se han realizado hasta el momento y el señalamiento de su importancia metodológica en lo que hemos denominado análisis dialéctico del significado ${ }^{3}$.

\section{EL ASPECTO EMOTIVO DEL LENGUAJE: BREVE PANORAMA HISTÓRICO}

Desde que ya Platón en el Crátilo intentase liberar al pensamiento de la estrecha relación entre palabra y cosa, proyectándolo sobre el eidos y buscase el logos en la antagónica estructura de nomos y phisis, puesto que las palabras no ofrecían la naturaleza de su objeto; en oposición al planteamiento contrario, que se interesaba más por el funcionamiento y las relaciones que puedan establecerse entre las palabras ${ }^{4}$, la concepción del lenguaje como un símbolo, que es representación de nosotros mismos, y después de las cosas, ha llevado a diferentes

2 Aunque el hablante no signifique con sus palabras nada que no esté potencialmente en la lengua, a veces puede emplear las palabras para significar algo más de lo que éstas significan denotativamente en la lengua. Por ello, si hablamos literalmente y queremos decir aquello que nuestras palabras significan, no habrá diferencias entre el significado linguístico y el significado del hablante, pero si no hablamos literalmente sí la habrá. Queda pues justificada la distinción de Lázaro Carreter entre lenguaje literal y no literal recogida en nuestras palabras; cf. F. Lázaro Carreter, «Mensaje» apud Lingüística, pp. 159 y ss.

3 Con la noción de análisis dialéctico del significado nos referimos al modelo metodológico que, partiendo del carácter interdisciplinar del significado que trasciende el ámbito lingüístico para adentrarse en los campos de una semántica sintomática y filosófica, elaboramos para la determinación, estructuración e interpretación de los significados totales, por llamarlos de alguna manera, y que se basaba en la aplicación de un modelo linguístico para la descripción de los significados denotativos (tesis), un modelo en cierto modo más cercano al ámbito literario (semántica sintomática) para la explicación de los significados emotivos (antítesis) y, finalmente, un modelo filosófico basado en la hermenéutica crítico estructural del lenguaje que, como síntesis dialéctica del proceso metodológico anterior, tenía por finalidad la interpretación de los significados denotativos y emotivos en un marco general globalizante; al respecto puede verse nuestro trabajo «Interpretación dialéctica», Analecta Malacitana, pp. 315-333.

4 Para lo que sigue es interesante la reflexión teórica que puede verse en E. Lledó, Filosofía, pp. 1347. 
formulaciones empíricas en las que lo importante no es ya que las palabras muestren las cosas, sino el procedimiento interno que permite esta mostración. Se trata, como puede comprenderse a simple vista, de un planteamiento lógico u ontológico de justificación del fenómeno lingüístico desde el ámbito teórico de la lengua como objeto empírico, como vehículo de expresión de la trascendencia del lenguaje sujeto, incognoscible directamente por su inmaterialidad.

Pese a ello, la nueva empiricidad de los planteamientos psicologistas dejan paso ahora a la faceta más inmanente del lenguaje, el habla, patente en los planteamientos de Locke, por poner un caso, para quien existe una conexión esencial entre el pensamiento y la expresión.

Aunque parece evidente, debido entre otras razones al creciente auge del polo empírico que atraviesa la clásica dialéctica entre formalismo y ontologismo, la formulación tanto teórica como metodológica de un signo lingüístico que se concibe no como una representación de conceptos en el sentido de contenidos mentales sino como un simple «deslindamiento de unidades» susceptibles de variación y de diferente empleo de acuerdo con la estructura de una lengua ${ }^{5}$, no debe olvidarse ni caer en el error de ignorar la importante aportación del racionalismo cartesiano, que instaura la búsqueda de un lenguaje universal, que debe ser instrumento de la Razón, lo que conlleva una equiparación del análisis de contenidos con su correspondiente formalización, que se alzan como dos procesos que han de marchar correlativos.

Este trascendentalismo incipiente cobra importancia con la figura de Kant, a quien debemos la introducción del concepto de genio y lo que ello supone para la teoría literaria moderna, pues, desde ahora, el lenguaje no será sólo representativo, sino expresión de lo emocional e impulsivo ${ }^{6}$.

Por ello, y como sostiene Herder, el lenguaje no es ya sólo un instrumento, sino que el acto de pensar mismo es un acto del lenguaje, lo que confiere al hombre un carácter de criatura de lenguaje, de ser activo y con libertad de pensar, cuyas fuerzas progresan continuamente. De esta manera, de órgano, el lenguaje se ha convertido en organismo: es el creador del hombre mismo, es un modo y una determinación de la energía del espíritu?

Estas dimensiones diferentes han llevado al lenguaje a instaurarse como sujeto de distintas disciplinas, según sea la faceta de él que predomine; a saber, de la lingüística, si lo consideramos como ergon, de la psicología del lenguaje, si lo hacemos como dynamis y, finalmente, de la filosofía, si lo consideramos ahora como energeia. Con ello, son dos los principios que pueden establecerse del planteamiento humboldtiano:

5 Cf. J. A. Collado, Lingüística, pp. 96 y ss.

6 Cf. R. Wellek, Historia, Tomo I, pp. 262-268.

7 Con Herder se produce una ruptura con el pasado neoclásico. Radical en sus ideas y en el modo de exposición, sostiene que la crítica es un proceso de identificación intuitivo y oscuramente racional, lo que equivale a decir que la crítica sin genio no es nada; un panorama general al respecto puede verse en $\mathrm{R}$. Wellek, Historia, Tomo I, pp. 211-232. 
- lenguaje como actividad, como creación del que habla, siendo al mismo tiempo subjetivo (puesto que no es algo dado por el mundo exterior, sino un modo peculiar de representar en nosotros ese mundo), y objetivo (ya que es obra de una nación a lo largo de su historia y, por consiguiente, extraño al individuo);

- y, finalmente, lenguaje como organismo, ya que, de hecho, no se trata sólo de un medio para expresar la Verdad, sino de un camino para descubrir aquello que no conocemos.

La observación de lo expuesto hasta aquí nos lleva a una conclusión sobre la que ya hemos tratado en otra ocasión y que resulta obvia: se trata del nuevo rumbo que toma el lenguaje a partir de Kant, que deja de ser un mero vehículo representativo para convertirse en expresión de lo emocional (y más aún como institución social y sistema de leyes específicas, sui generis $)^{8}$.

Con ello, y sin querer entrar en la polémica de que exista un registro emotivo que se aparte del denotativo", lo cierto es que se pone de relieve la pluralidad del acto comunicativo en el que la expresión de la emoción y de los aspectos no referenciales tiene capital importancia, de ahí la necesidad de explicar este significado emotivo, muchas veces inaprehensible tras una única lectura literal.

\section{APROXIMACIÓN EXPLICATIVA AL SIGNIFICADO EMOTIVO}

\subsection{El problema del sentido}

Para situar la significación connotada en el ámbito metodológico que presentamos, vamos a comenzar distinguiendo la palabra del sentido. Sin lugar a dudas, la palabra como elemento del lenguaje siempre designa determinado objeto, característica o relación, y el lenguaje consiste en un sistema de códigos complejos que introducen la cosa en un sistema de enlaces y relaciones ${ }^{10}$; por ello, no puede dudarse que la estructura de la palabra es compleja, ya que, frente a la relación objetal, es decir, a la designación de un objeto y a la evocación de todo un campo semántico, la palabra tiene una función de significado determinado

8 Como ya explicamos con anterioridad, cf. J. L. Jiménez, «Teoría», pág. 410, lo que ello entraña es una primera formulación, todavía rudimentaria e imperfecta, de lo que será la función poética del lenguaje de Jakobson, caracterizada principalmente por el hecho de que el mensaje crea su propia realidad; cf. R. Jakobson, «Lingüística y poética» apud Ensayos, pp. 347-395.

9 En realidad, como hemos dicho anteriormente, se trata de dos usos fundamentales del lenguaje: el literal y el no literal; el primero, empleado en comunicaciones que deben ser descifradas en sus propios términos; y el segundo, en comunicaciones en las que ocurre todo lo contrario; cf. F. Lázaro Carreter, «Mensaje» apud Lingüistica, pp. 149-171.

${ }^{10}$ Efectivamente, la palabra es el producto de un largo desarrollo en cuyo proceso se separa del contexto sinpráxico y se convierte en un sistema autónomo de códigos que dispone de distintos medios para la designación de cualquier objeto y para la expresión de cualquier enlace y relación. El desarrollo del lenguaje es el proceso de emancipación del carácter simpráxico y la separación de la palabra como un sistema sinsemántico; cf. A. Luria, Lenguaje, pp. 30-34. 
que separa los rasgos y los generaliza, que analiza el objeto y lo introduce en una determinada categoría y, finalmente, transmite la experiencia de la humanidad ${ }^{11}$.

Desde este punto de vista, la ciencia del significado tendría por objeto el estudio de la relación entre la palabra y el hecho, frente a la concepción primitiva en la que el nombre indicaba o describía una $\operatorname{cosa}^{12}$ (recuérdese que, incluso ya para Saussure, el lenguaje no era integral porque implicaba sonidos que llevaban ideas que, a su vez, dependían del lado social e individual). Ello explica que las relaciones directas de significación entre palabra y cosa sean la fuente de casi todas las dificultades del pensamiento y el creciente interés por el estudio del sentimiento y de la voluntad ${ }^{13}$, que ha llevado a constatar empíricamente el hecho de que las representaciones potenciales a disposición del individuo puedan ser diversas según la base sobre las que se asienten las significaciones de una palabra y los diversos materiales que a esa base se allegen. Por consiguiente, la base de un vocabulario será el sentido que se les dé a las palabras ${ }^{14}$, sentido que es distinto para diferentes individuos y que, incluso para una misma persona, no es consubstancial a las palabras porque las representaciones imaginativas carecen de imagen fija, y las intuitivas se emplean como símbolos sin acompañarse con la idea de la cosa que representan ${ }^{15}$.

Sin lugar a dudas, la asociación es uno de los principios que rigen la actividad expresiva e influye en la formación y vida de las lenguas, manifestándose en la

${ }^{11}$ Además, la palabra permite al hombre salir de los límites de la percepción inmediata, asegurando con ello el salto de lo sensible a lo racional, que constituye la característica esencial de la conciencia humana; y tiene también funciones léxicas, es decir, entra en determinadas clases de relaciones semánticas. Al respecto es interesante el capítulo «La palabra y su estructuras semántica» de A. Luria, Lenguaje, en especial las pp. 40-46.

${ }_{12}$ Así, por ejemplo, los substantivos son signos aplicados a las cosas, el lenguaje obtiene una idea que se relaciona luego con un nombre y éste se hace signo; cf. C. K. Ogden y A. R. Richards, Significado, pp. 23 y ss.

${ }_{13}$ Se considerará al sujeto que habla como agente de los hechos semánticos y el medio social en el que se difunden hasta ser expresiones de la lengua; cf. F. Restrepo, Semántica, pp. 151 y ss.

${ }^{14}$ Cualquier expresión es la acción de manifestar el pensamiento por medio del lenguaje. Sin embargo, no expresamos nunca un pensamiento puro y abstracto, sino un contenido complejo que presenta un triple valor de interés: uso nocional o gnómico (en cierto modo una lógica de la expresión); otro expresivo, más o menos inconsciente; $y$, finalmente, uno impresivo o intencional, en el que debe distinguirse la intención directa o natural de una segunda intención que constituye un valor estilístico; cf. P. Guiraud, Estilística, pp. 51 y ss.

${ }_{15}$ Aunque existe un proceso por el cual se introduce o especifica un término en el discurso; A. Kaplan llama a tal proceso especificación del signifićado y afirma que se realiza mediante el concepto de definición; «equivalencia lógica entre el término definido y la expresión cuyo significado ha especificado», tal definición no siempre es satisfactoria en lograr la especificación. Dado que el concepto de definición no provee una descripción lógica, la especificación del lenguaje es hipotética y provisional, y como el proceso de investigación es una abstracción de investigaciones particulares, el concepto tiene varios significados en diferentes contextos que no son equivalentes lógicos, sino que coinciden en mayor o menor grado. $\mathrm{Si}$ la representación del lenguaje se hace en términos abstractos y generales no hay problemas. Éstos surgen cuando se pretende dar a la representación un contenido específico que provenga de algún campo particular de investigación. Los problemas se deben a las exigencias lógicas de los variados contextos en que funciona el concepto; cf. A. Kaplan, «Significado» apud M. Bunge, Semántica, pp. 76 y ss. 
analogía o tendencia imitadora y unificadora. Es cierto que algunas de estas creaciones son individuales o pasajeras, pero también es cierto y constatable que otras se generalizan y propagan llegando a formar parte no sólo del habla popular ${ }^{16}$, sino también de la propia lengua.

Otras veces, cuando al aprender palabras, les atribuimos significados que no les corresponden, principalmente por la semejanza en los sonidos de las mismas, llegamos a deducir significados erróneos por analogía con otras voces ya conocidas.

Otro proceso igualmente interesante es el automatismo ideológico, que se produce en la fase práctica en la que la palabra se torna símbolo ${ }^{17}$, tras una primera fase etimológica, en la que se busca el nacimiento del nombre de la palabra. Este fenómeno se explica por la falta de representaciones intuitivas y consiste en que la voluntad ejecuta acciones que a fuerza de repetirse han llegado a ser habituales inconsciente y automáticamente al solo impulso de las representaciones que con ella coinciden ${ }^{18}$.

El problema está, en definitiva, en saber si el signo tiene un valor, si lo significado tiene un valor, y si estos dos valores son iguales ${ }^{19}$, puesto que el sentido de una palabra no es cuantitativamente mensurable. Por ello, el estudio que la disciplina simbólica hace del lenguaje en los asuntos humanos y de los símbolos que influyen en el pensamiento, le lleva al análisis y clasificación tanto de las cosas como de los pensamientos, que se erigen como lo dirigido y organizado, lo registrado y, en suma, comunicado; lo que justifica el hecho de que las palabras no signifiquen nada por sí mismas, sino en un corpus, en el que adquieren también la función emotiva ${ }^{20}$ que nos interesa.

${ }^{16}$ En cierto modo, ello ha provocado la distinción entre dos tipos de estudios estilísticos fundamentales; a saber, una estilistica de la expresión, que estudia las relaciones de la forma con el pensamiento; y una estilística del individuo, que estudia las relaciones de la expresión con el individuo o con la colectividad que la crea o la utiliza; cf. P. Guiraud, Estilística, pp. 35 y ss.

${ }^{17}$ La función del símbolo verbal consiste en mantener unidos por la fuerza atributos contradictorios, aunque todos ellos no puedan quizá presentarse al espíritu al mismo tiempo porque se inhiben unos a otros; cf. C. K. Ogden y A. R. Richards, Significado, pág. 59.

${ }^{18}$ Cf. F. Restrepo, «Influencias psicológicas y sociales» apud Semántica, pp. 151-230.

${ }^{19}$ Cf. E. Gilson, Lingüística, pág. 63.

20 Sin lugar a dudas, el objetivo consiste en buscar la forma de establecer una ruta que nos lleve al sentido del texto. A modo de ejemplificación citamos aquí distintas posturas:

- método de composición estática: estudio de la posición de los valores del texto en su estado actual. Su relación es sobre todo estética (cantidades, distribución, proporción, etc.) y sus valores sobre todo literarios (palabras, clases de palabras, fórmulas, etc.);

- método arqueológico o genético: estudio del texto por ahondamiento en sus distintos estratos. Apreciación del distanciamiento de los unos con respecto a los otros; tal es el aspecto arqueológico. Sentido del paso de un estrato a otro; tal es el aspecto genético. Utiliza los deshechos del método anterior, partiendo de las rupturas, no de las armonías;

- método de la historia de las formas: plantea la naturaleza del texto en función de su finalidad o función social y general;

- método de las series: se trata de situar al tex to como conjunto en una línea de textos análogos; etc.

Cf. B. Beauchamp, «La búsqueda del sentido» apud AAVV, Hermenéutica, pp. 53-58. 


\subsection{Lenguaje, representación y comunicación}

Los problemas que se derivan del estudio y análisis del significado han sido reconocidos y considerados con atención durante todo el período de la historia intelectual del hombre ${ }^{21}$. En este sentido, la originalidad del estructuralismo lingüístico consistió en la nueva significación que se le dio a la estructura; en la transformación de esa noción, para que remitiese a algo diferente a la simple idea de organización existente ya en la gramática tradicional. Los filósofos, hasta el pasado siglo, definían la lengua como expresión del pensamiento, como un calco de la realidad lógica o psicológica, frente al historiador del estructuralismo que no reconoce la organización lingüística que no esté racionalmente motivada, pues el único orden posible entre las palabras es el de las $\operatorname{cosas}^{22}$. Esta idea decimonónica entronca con una nueva manera de considerar la descomposición de la palabra en la que se tiene en cuenta la arbitrariedad de la organización interna de sus sonidos y, en el orden semántico, el descubrimiento de que los componentes de las palabras tienen una organización que no responde a un orden exterior sino a un orden jerárquico ${ }^{23}$. Así, tan pronto la palabra se destruye o se transforma, el espíritu la deja de considerar una imagen de sí y la considera sólo como un instrumento para la comunicación, lo que significa, de hecho, una auténtica ruptura epistemológica en sentido bachelardiano, ya que la preocupación por la representación ha cedido su lugar a la preocupación por la comunicación $^{24}$.

${ }^{21}$ La mayor parte de este trabajo ha sido llevado a cabo por filósofos, especialmente lógicos. El interés del lingüista por el uso del lenguaje es mucho más amplio; las deducciones de la lógica formal y los discursos filosóficos en general son una parte importante del uso del lenguaje por los hombres, pero de ninguna manera son los únicos usos. El interés del lingüista se refiere al lenguaje en todos sus usos y manifestaciones como parte del proceso de la vida cotidiana y de la interacción social de miembros de diferentes grupos; por tanto, la aproximación al significado por parte del linguiista debe basarse en este uso mucho más amplio del lenguaje y tipos de enunciados; cf. R. H. Robins, «La Semántica» apud Lingüística, pág. 43.

${ }^{22}$ Aunque el lenguaje es pensamiento en el sentido de percepción del significado de las palabras, tanto en forma de conceptos como en forma de representaciones que la acompañan, la tesis del papel activo del lenguaje se puede interpretar en un triple sentido;

- sin el lenguaje como sistema de reglas gramaticales y de significados, el pensamiento conceptual sería imposible;

- el lenguaje es la base social existente del pensamiento individual; éste es creador y siempre nuevo, si no sería imposible el progreso del saber y la cultura;

- el tercer sentido trata de un análisis especial a causa de su significación y trascendencia; el lenguaje actúa también sobre la capacidad de abstracción y generalización del pensamiento; el lenguaje es un reflejo particular de la realidad y a su vez es el creador de nuestra imagen de la realidad (cf. A. Schaff, Lenguaje, pp. 243-251).

${ }^{23}$ Las ideas de Humboldt están ya muy cercanas al concepto de estructura, pero no logran desarrollarse hasta Saussure porque no resistieron el descubrimiento de la transformación de las lenguas (que no guarda relación con la organización interna de las mismas); cf. O. Ducrot, Lingüística, pp. 17-49.

24 Efectivamente, no se puede hablar para no decir nada porque lo que se dice tiene el sentido de las palabras pronunciadas; el decir algo implica el haber pensado lo dicho y el comunicar lo pensado; cf. E. Gilson, Lingüistica, pp. 128-129. 
Durante un largo período de la historia de los estudios semánticos y todavía hoy hasta un punto considerable, la investigación del significado se ha basado en las relaciones de referencia y denotación y, aunque es cierto que el significado incluye la relación entre el enunciado y las partes del enunciado y el mundo exterior, y que la referencia y la denotación se encuentran entre tales relaciones, también es cierto que para el propósito de la linguiística es de desear que el significado sea tratado de una manera más comprehensiva ${ }^{25}$.

La referencia o la denotación son claramente parte del significado de muchas palabras. Por el uso que se hace en la frase de ciertas palabras es posible captar el ambiente, determinados procesos y cualidades, etc.; por ello, la relación entre la palabra y aquello a lo que se puede referir no es sencilla. Muchas veces se ha dicho que el significado de una palabra es la idea que suscita en la mente del hablante, lo que complica inevitablemente la teoría semántica ${ }^{26}$ puesto que, desde el punto de vista del hablante, el hablar aparece como un medio de acción y de expresión y desde el punto de vista del oyente, como una fuente de impresiones y de reacciones.

Todo sistema de significación posee un plano de expresión y otro de contenido, y la significación coincide con la relación de ambos planos; pero cuando este sistema se convierte en elemento de otro sistema se produce la inserción de uno en otro a la vez que su desligamiento; procedimiento éste que puede efectuarse de dos maneras, dando lugar a dos conjuntos opuestos:

- si el primer sistema se convierte en plano de la expresión del segundo sistema, su relación se verifica por la semiótica connotativa: el primer sistema sería el plano de la denotación, y el segundo, el plano de la connotación ${ }^{27}$;

- en caso de que el primer sistema se convierta en plano del contenido del segundo, dará lugar a los metalenguajes o sistemas donde el plano del contenido está constituido por un sistema de significación.

En este sentido, la connotación como sistema comprende significante, significado, y el proceso que los une (significación). Los significantes de la connota-

${ }^{25} \mathrm{La}$ actividad significativa del habla consta, en primer lugar, no de las palabras como tales sino de enunciados o extensiones del habla que consisten en frases y están delimitadas por pausas. Los enunciados tienen significado, son significativos; por tanto, el significado de una palabra puede ser considerado también como la manera en que se la usa como parte de frases diferentes. Lo que el diccionario hace es tratar de resumir, en el caso de cada palabra, la manera o maneras en que se la usa en las distintas clases de frases en que se la encuentra en la lengua; cf. R. H. Robins, «La Semántica» apud Lingüística, pp. 4445.

${ }^{26}$ La escuela alemana ve en la estilística de una lengua el estudio de sus caracteres lingüísticos que, a su vez, reflejan los caracteres psíquicos de la colectividad que la habla. El ser humano encuentra en cada sondeo sobre sí mismo la sucesión ininterrumpida de sus estados de conciencia. Esta instrospección rara vez permite al sujeto objetivarse; rara vez se ve a sí mismo como lo vería otro: lo que los otros perciben de uno son las manifestaciones exteriores de nuestro ser, no ven más que los resultados y los símbolos, en forma de actos; y en el lenguaje ocurre también así; cf. Ch. Bally, Lenguaje, pp. 81 y ss.

${ }^{27}$ En definitiva, todo sistema connotado es aquel cuyo plano de expresión está constituido por un sistema de significación, es un sistema segundo con relación al denotativo; cf. A. J. Greimas, Sentido, pág. 102. 
ción son signos del sistema denotado. Mientras el significado de la connotación es un fragmento de ideología a través del cual el mundo penetra al sistema; la ideología será la forma de los significados de la connotación y las imágenes la forma de los significantes de la connotación.

\subsection{Imagen psíquica y significación lingüística}

Desde muy antiguo todos los autores destacaron la importancia de las imágenes y aunque después hubo una reacción contra el virtuosismo en el estilo, que algunos autores quisieron reemplazar por un idioma sencillo, descrito como grado cero, no debe pensarse que estas críticas iban dirigidas contra las imágenes funcionales que formaban parte de la textura de un texto; lo hacían contra las imágenes artificiales y ornamentales exclusivamente.

Por ello, el interés que ha suscitado el estudio de las imágenes ha sido generalizado y de creciente auge y, en un sentido estrictamente lingüístico, como una figura que expresa alguna semejanza o analogía ${ }^{28}$ y que da forma al significado emotivo, ha sido caracterizada por: 1) convertirse en símbolo que expresa de una forma memorable uno de los temas principales de un texto; 2) expresar sensaciones alucinatorias del único modo que le es factible al autor; 3 ) comunicar juicios implícitos de valor; 4) expresar las aspiraciones personales del autor; y 5) permitir al autor que hable de experiencias que no habrían podido expresarse de otra manera ${ }^{29}$.

Todo ello justifica que su estudio deba ser el primer paso que nos permita llegar al significado emotivo e incluso, si consideramos el planteamiento desde un punto de vista ontogenético, nuestra afirmación queda corroborada al recordar que, ya en las primeras etapas, la palabra estaba entrelazada con la situación, el gesto, la mímica y la entonación y que luego comenzaba un proceso de separabilidad en el que designa no al objeto, sino sólo a algún rasgo de ese objeto. Ello explica el significado difuso y ampliado que posee la palabra y la conservación de un estrecho vínculo con la acción práctica; por eso puede perder fácilmente su referencia objetal y, lo que es más importante, adquirir un nuevo significado en correspondencia con uno u otro rasgo del objeto ${ }^{30}$.

${ }^{28}$ Toda imagen poética es, en cierto modo, metafórica: dos objetos o ideas pueden asociarse entre sí de dos maneras, a saber, por semejanza o por contigüidad, por el hecho de que existan en el mismo contexto metal. También es cierto que el término imagen continúa siendo un tanto ambiguo pues hay metáforas y comparaciones que no pueden reputarse como imágenes; de ahí que no puede hablarse de imagen amenos que la similitud que exprese tenga una cualidad concreta y sensible; cf. S. Ullmann, Lenguaje, pp. 206 y ss.

${ }^{29}$ Con ello no queremos decir que la relación entre la imagen y la realidad extralingüística sea referencial, ni mucho menos. Somos conscientes de que el signo denota un objeto perceptible y de que la representación es una imagen interior que no siempre se liga con el mismo sentido, lo que supone una de las más grandes dificultades que presenta su sistematización; cf. H. Brekle, Sémantique, pág. 50.

${ }^{30}$ Cf. A. Luria, Lenguaje, pp. 55-61. 
Frente a la significación, también debemos considerar el lugar no linguístico en el que se sitúa la aprehensión de la significación, es decir, la percepción, puesto que la explicación de los hechos estéticos se sitúa hoy, generalmente, en el plano de la percepción del discurso ${ }^{31}$.

Por ello, cuando atendemos al lenguaje en cuanto proceso vivo, no es posible la abstracción y segregación del sujeto y aún cuando a todos se nos alcanzan las dificultades para edificar una sistemática científica del tipo de la lingüística de la connotación, la mejor forma de acercarse a esta perspectiva es bajo la consideración del lenguaje como expresión ${ }^{32}$. Así pues, la emoción presenta una estructura definida ${ }^{33}$ que tiene la función de orientar al hombre respecto a su ambiente y que, en cuanto actividad teórica, supone una integración de las situaciones. Por ello, el lenguaje sirve para objetivar, aunque siempre emoción e inteligencia se entremezclan ${ }^{34}$.

Por consiguiente, el lenguaje expresivo no transmite sólo información, sino también sentimientos y actitudes, lo que le confiere un carácter particular, en cierto modo apartado de las reglas de la semántica y la sintaxis estrictas ${ }^{35}$.

De esta forma, cuando un hablante ve un objeto (referente, designatum) y construye su imagen del mismo mediante un símbolo verbal (designata), éste se constituye en el significante primero, síncrono con el hablante que se constituye

${ }^{3 !}$ Por ello, las significaciones del mundo humano se sitúan en el plano de la percepción (lo que equivale a circunscribir su estudio al interior del mundo del sentido común o, como se suele decir, del mundo sensible). La semántica puede ser considerada entonces como una tentativa de descripción del mundo de las cualidades sensibles; los significantes como los elementos que hacen posible la aparición de la significación en el plano de la percepción y que son reconocidos, en este mismo momento, como exteriores al hombre; el significado como las significaciones que son recubiertas por el significante y manifestadas gracias a su existencia; cf. A. J. Greimas, Semántica, pp. 12-15.

${ }^{32}$ Todavía en los lenguajes más formalizados se contiene siempre el componente expresivo, de manera que el sujeto está más o menos visible; cf. C. Castilla del Pino, Hermenéutica, pp. 29-32.

${ }_{33}$ Tal y como reconoce F. Meix Izquierdo, Dialéctica, pp. 131-135 y como desarrollamos en nuestro trabajo «Teoría», aunque la imagen psíquica sea una entidad desprovista de intencionalidad, un reflejo perceptivo, se trata de un esquema o pauta de relación del individuo con su mundo y, por tanto, no de un reflejo. De esta manera, la distinción clásica entre imagen (derivada del dato perceptivo) e imaginación (imagen creadora) pierde sentido puesto que los objetos no existen en un espacio ideal; tienen una situacionalidad y no son percibidos de manera neutra sino que tienen cualidades afectivas que no son simples proyecciones emotivas individuales sino que son inherentes a la relación perceptiva sujeto-objeto y, consecuentemente, presentan una estructura definida; cf. J. L. Jiménez, «Teoría», pp. 412 y ss.

${ }^{34}$ De ahí la distinción sostenida por muchos semantistas entre significado cognitivo y emotivo. Los términos en sí mismos reflejan claramente la concepción de que el uso del lenguaje incluye dos o más facultades psicológicas diferenciables: el intelecto, por una parte, y la emoción y la imaginación, por otra. Uno de los aspectos que más atención recibe tanto en los trabajos especializados de semántica, como en obras de vulgarización sobre esta disciplina es la importancia de los factores emotivos en el comportamiento lingüístico; cf. J. Lyons, «Significado cognitivo y emotivo» apud Lingüistica, pp. 461-462.

${ }^{35}$ En efecto, el uso poético del lenguaje, por ejemplo, extingue los valores del argumento en favor de los valores de expresión y encantamiento, restituye la materialidad del significante y del significado convirtiéndolos en valores esenciales en los que el mundo es aprehendido como una totalidad individual de momentos y situaciones centradas en una imagen, la cual se produce cuando el ego se sumerge en la perspectiva y se liga al mundo por su situación y al espíritu por sus reminiscencias a expectativas; cf. $\mathrm{N}$. Mouloud, «Significación, lenguaje y estructura» apud AAVV, Estructuralismo, pp. 43-70. 
en significante segundo ${ }^{36}$. Y aunque para el oyente ambos significantes se dan con igual significado en las frases indicativas, debe considerarse el aspecto diferenciador que ambos significantes conllevan en las frases emotivas ${ }^{37}$, lo que nos conduce, inevitablemente, a una reflexión seria en torno al grado de realidad del significado cuya conclusión más importante consiste en la consideración de que el significado no es una «cosa», sino la representación psíquica de la $\left\langle\cos a »^{38}\right.$, una representación que lleva al sujeto a descubrir nuevos aspectos del mundo y a reconstruir su lenguaje gracias a la metáfora entendida como superación de los significados establecidos en la lengua ${ }^{39}$.

\section{CONCEPCIONES SOBRE LA SIGNIFICACIÓN EMOTIVA: LA CON- NOTACIÓN}

\subsection{Concepto de connotación}

Una semántica sintomática orientada a la explicación del significado se basa en la noción de que todo uso literario del lenguaje es esencialmente

${ }^{36}$ Así pues, lejos de un análisis formalista, las interrelaciones de los distintos niveles de emotividad creativa nos darán la significación de un discurso o campo, es decir, las distintas modalidades en que el sentido se diversifica (ocultaciones, desvíos desde el inconsciente, influencias fonéticas y semánticas, etc.).

La imagen evocada sirve así de puente entre la imagen perceptiva (que se produce en presencia del objeto) y la creativa (que prescinde de cualquier modelo preexistente). De hecho, el lenguaje no se limita a confirmar las estructuras perceptivas existentes, sino que, una vez asimiladas por la comunidad, las reconstruye creativamente en el curso de una actividad poética. De este modo, tanto el lenguaje como la realidad están sometidos a las categorías significativas que les impone la valoración perceptiva previa. Cada vez que convertimos un signo de experiencia en una combinación de signos lingüísticos, sólo aprovechamos algunos aspectos que suponemos notables para el que nos escucha. El signo de experiencia, por cuanto está asentado en el mundo íntimo de los hechos subjetivos, es esencialmente individual, siempre único; cf. R. Cerdá, «Cosa, idea y palabra» apud Lingüística, pp. 59-82. Por todo ello, la naturaleza de la imagen es metafórica; cf., entre otros, S. Ulimann, Semántica, pp. 239-246; M. Black, Modelos, pp. 28-56; Ch. Kany, Semántica, pp. 40-84; A. R. Fernández et alii, Semántica, pp. 100-108; C. Kerbrat-Orecchioni, Connotación, pp. 163-175; etc.

${ }^{37}$ Una teoría actual del significado debe dar entrada tanto al significado léxico cuanto a la posibilidad de su sustitución por la significatividad que un hablante le confiere en un momento en un contexto concreto valiéndose de una serie de recursos; cf. al respecto C. Castilla del Pino, «Imprecisión, opción y significatividad» apud Hermenéutica, pp. 50-55.

${ }^{38}$ Efectivamente, el significado no es ni la representación psíquica ni la cosa real, ni lo decible, según creían los estoicos, no es tampoco el acto de conciencia, ni la realidad; de ahí que no pueda ser definido nada más que dentro de un proceso de significación; cf. R. Barthes, Semiología, pág. 35.

${ }^{39}$ Estas ideas han dado lugar al estructuralismo psicoanalítico que pretende ocupar el lugar de la representación al haberse fijado como tarea el hacer hablar, a través de la conciencia, al discurso del inconsciente. El lenguaje es el único instrumento capaz de descentrar nuestra concepción espontánea del sujeto y darnos acceso a ese otro, inadvertido o recusado, pues el lenguaje no expresa toda la experiencia analítica. Más allá de la palabra total existe un mundo no expresado. El instrumento lingüístico no es más que la traducción verbal de la realidad mental misma e incluye en ella su condicionamiento material, psíquico y orgánico. Sobre el estructuralismo psicoanalítico y todo su desarrollo puede verse: M. Covez, Estructuralistas, pp. 85-113; T. Segovia, Lenguaje, pp. 113-155; R. Santerre, «El método de análisis en las Ciencias Humanas» apud Estructuralismo, pp. 27-63; y P. Daix, Estructuralismo, pp. 135-153; entre otros. 
plurisignificativo. De este modo, no debe causar extrañeza que una de las características específicas del uso literario del lenguaje que de modo más flagrante opera con el significado reciba, en el seno de nuestra explicación, atención especial: nos referimos al carácter connotativo de este uso. Representando, como nos enseña la lingüística, una actitud subjetiva del escritor ante la denotación ${ }^{40}$, la connotación implica, como consecuencia inmediata de su instauración en el enunciado, el establecimiento de una polivalencia significativa deducida de la imposición de valores suplementarios sobrepuestos a una función puramente informativa del lenguaje ${ }^{41}$.

La connotación, por tanto, es una selección de propiedades que no se encuentran por sí mismas en ninguna parte; son entidades ficticias o nominales que nos vemos obligados a considerar a raíz de la analogía por la cual tratamos ciertas partes de nuestros símbolos como si fueran completos por sí mismos. Las propiedades utilizadas para determinar la aplicación de un símbolo, en virtud de las cuales algo es miembro del conjunto que es la denotación son, pues, las connotaciones de un simbolo ${ }^{42}$.

$\mathrm{Y}$, aunque es conocido por todos el hecho de que las palabras denotan objetos y éstos son lo que decimos por medio de las palabras, también debe subrayarse que éstas connotan sentidos y que el sentido de las palabras es algo más que la

4) No debe identificarse plenamente connotación y subjetividad. Es muy probable que los semas sintomáticos -en los que se apoya la acción poética, por ejemplo- estén en el significado léxico con independencia de su actualización y que la materia de la que estén hechos provenga de la significación denotativa y se base en la polisemia y en la sinonimia; semas virtuales con los que la lengua y sus hablantes «juegan». Además, aunque pueda ser cierto que algunos tipos de connotación sean estrictamente idiolectales, hay otras que, pese a ser reconocidas como auténticas connotaciones (los niveles de lengua, por poner un caso) pertenecen al diasistema, están institucionalizadas. Por otro lado, el valor denotativo de un término puede variar de un idiolecto a otro; de ahí que no deba identificarse plenamente connotación con subjetividad y denotación con objetividad. Sobre la virtualidad de la lengua y sus manifestaciones puede verse A. J. Greimas, Semántica, pp. 57 y ss.; y C. Kerbrat-Orecchioni, Connotación, pp. 18-19.

${ }^{41}$ De lo que se ha dicho resulta obvio que la explicación de los significados connotativos no puede prescindir del conocimiento de la denotación, sobre todo cuandoes visible que la utilización de un vocablo ha obedecido a una selección intencional. Por ello, se impone la previa descripción lingüística de los significados denotativos como paso previo de la explicación de los significados connotativos; cf. C. Reis, Análisis, pp. 134-143; y J. L. Jiménez Ruiz, «Significados denotativos», pp. 61-98.

${ }^{42}$ Como hemos dicho, la connotación de una palabra es un conjunto de entidades nominales. Existen distintos métodos para decir cuáles son éstas:

- atender al uso lingüistico: el solo conocimiento del uso del lenguaje es suficiente para saber qué significa una frase; según este método la connotación de una palabra se tornaría indiscernible en su significado en el sentido de las otras palabras agregadas a una palabra en el diccionario;

- la referencia que utiliza una palabra determina sus referentes (denotación) que, a su vez, determinan cuáles son las distintas referencias que pueden hacerse a ellos; dos símbolos tendrían entonces la misma connotación cuando simbolizan referencias similares; la connotación de una referencia estaría compuestá por aquellos caracteres de su referente en virtud de los cuales éste es aquello a que nos referimos.

Sobre el término connotación, la relación de denotación a connotación y los métodos para estudiar la connotación es interesante C. K. Ogden y A. R. Richards, Significado, pp. 197-219; aunque, debe tenerse en cuenta que connotación es un término con valor equivalente a intensión (frente a extensión) y que sólo con posterioridad a Bloomfield, al triunfar esta última pareja, se especializa con el valor actual. 
simple referencia objetal; ese algo más son los tres tipos de connotación que muy certeramente distingue $M$. Urban ${ }^{43}$; a saber:

- connotación conceptual, entendida como la referencia indirecta a predicados y cuya condición para su existencia es la presencia del universal intuitivo en el lenguaje; este tipo de connotación es entonces la referencia indirecta a universales abstractos;

- connotación emocional, en este caso como referencia indirecta al sentimiento o emoción con que la palabra está ligada como expresión (obsérvese que no se trata de una emoción particular sino, más bien, de una intención acumulada);

- y, finalmente, connotación intuitiva, en la que Urban parte de una contraposición entre lenguaje abstracto y conceptual de la ciencia, para después reconocer como falsa esta diferencia, una vez que le ha permitido deslindar lo que puede ser la referencia aislada a los datos externos.

Sea cual fuere la concepción que se adopte ${ }^{44}$, en todas ellas es vislumbrable la dicotomía entre una serie de aspectos; a saber, los valores referenciales frente a los suplementarios, el uso normal frente al desviado, el general frente al individual, y el significado de la lengua frente al del habla, entre otros ${ }^{45}$.

${ }^{43}$ La concepción de Urban está derivada de la fenomenología. Considera la naturaleza del lenguaje en su carácter único, frente a los behavioristas que lo consideran parte de la conducta. Separa el análisis lógico (trata sólo con el sentido implicativo y de las palabras y oraciones sólo en la medida en que constituyen el medio de tales sentidos) del fenomenológico (que trata de las funciones significativas del lenguaje como elemento de comunicación). Parte de las nociones de comprensión e interpretación para distinguir tres tipos de funciones del sentido: representativa, emotiva e indicativa, que coinciden con los tres tipos de connotaciones que distingue; cf. M. Urban, Lenguaje, pp. 103 y ss.

${ }^{44}$ Efectivamente, son muchas las nociones o concepciones que se pueden tener de la connotación; entre otras, recogemos distintas acepciones de la misma:

- connotación como significado definicional: todo lexema connota las propiedades atribuidas a la unidad culturai;

- connotación de las unidades semánticas que componen el significado: algunos componentes semánticos formarán parte del significado, otros no;

- connotación emotiva: significación en la que la reacción o estímulo es una descarga de emoción;

- connotación de hiponimia, hiperonimia y antonimia;

- connotación por traducción a otro sistema semiótico: un lexema puede connotar su traducción a otra lengua;

- connotación por artificio retórico: se utilizan las connotaciones metafóricas como resolución de una relación inesperada;

- connotación retórica y estilística: una cierta forma del mensaje puede connotar la corriente estilística a la que se atribuye o la visión ideológica que se sirve de esta forma;

- connotación axiológica global: una cadena de connotaciones puede asumir para el oyente valores positivos o negativos; etc.

Sobre la connotación desde una perspectiva semiótica puede verse U. Eco, Estructura, pp. 117-120; Signos, pp. 181-183; etc.

${ }^{45}$ Tal afirmación recoge el planteamiento de Gary-Prieur, quien considera que la connotación cubre hechos que se refieren a estudios sobre el plano del estilo o de los textos. Le interesa ver cómo puede usarse el sentido de connotación como redes significativas construidas por el texto. Considera que lo que para Hjelmslev son lenguajes de denotación y de connotación lleva a una oposición entre lengua, por un lado, y habla, como principio de creatividad, por otro; cf. M. N. Gary-Prieur, «Connotation», pp. 96-107. 
Por lo que respecta ahora a su función, en la medida en que supone en un escritor la creación de connotaciones prototípicas, no depende del lexema connotador considerado aisladamente ${ }^{46}$. Cuando se habla de la connotación perfectamente interpretable de un lexema aislado, ya no se constituye propiamente una connotación creadora; se trata de una connotación lexicalizada que ya no funciona como tal, porque aparece diacrónicamente integrada en el fenómeno de la denotación. Es el caso evidentemente de las llamadas metáforas !exicalizadas, procesos de lexicalización relativos al fenómeno de la connotación surgidos como consecuencia de la actividad de valorar $y$, consecuentemente. con un carácter emotivo que les confiere la entidad de connotaciones afectivas ${ }^{t 7}$.

\subsection{El estudio de la connotación en la lingüística}

Sin lugar a dudas, cuando se trata de realizar un análisis de la connotación, el estuciioso de la lengua debe adentrarse en el universo del significado, y éste resulta lin campo amplio, además de controvertido y discutido; por eso la linguística al establecer las bases de su pretendido estatuto científico, dejó de lado el estudio del significado, lo cedió a otras ciencias, o simplemente lo redujo de manera excesiva. $Y$ todo ello a pesar de que la lingǘstica siempre ha tenido la necesidad de interrogarse sobre la naturaleza del significado y de que esta preocupación ha producido pautas importantes en la constitución de la teoría semántica.

Evidentemente, y aunque la reflexión sobre el problema del significado no ha tenido su origen en el ámbito estrictamente lingüístico (de ahí que si queremos remontarnos a la búsqueda de los antecedentes sobre el significado debamos hacerlo en la filosofía $a^{48}$, donde se han desarrollado, desde los griegos, la mayoría de los sentidos y problemas de la connotación), la aportación fundamental hat sido la de los lingüistas, quienes se han acercado al análisis de la connotación desde un punto de vista exclusivamente lingüístico; recordemos, a continuación, las aportaciones más importantes que se han producido al respecto.

165 La connotación se deduce sintagmáticamente, es decir, de la telación del semena integrado en el Lexema connotador, con los otros signos del discurso concreto en el que valya incluido. De otro modo. ci receptor sólo pocináa de ducir la isotopía directa que, por otra parte, carecería de pleno sentido sin la isotopía tatente del metatex10, convenientemente interpretada; of. M. J. Fernándes Leboráns, Lue, pás. 76.

17 C. M. J. Fornández Leboráns, Lä, pág. 77.

ts La palabra connotación tuvo su origen y el de varios de sus significados en la lógica de la excolástical, específicanente en la Summa Logicac de G. de Ockham, en la que introduce la distinción entre téminos absolates y connolatives. Los absolutes son aquellos que signilican de un mismo modo lo que significin, no tienen un significado principal y otro secundario, mientras los comnotativos tienen una doble signilicación simultánca, principal y secundaria, una doble referencia: a la sustancia y a buatidad intherente a la sustancia. Así, el sentido de la connotación como segundo significado cetri doctmentado deste cl siglo XIV en la semántica que surge de la lógica escolástica donde se desarrolia el problema de he conncataión en la ́coría de las propietates teminortum. Sobre los origenes fïlosóficos del problema de a countación puede consultarse B. Gara Cuarón, Connotación, pp. 7-42; y C. Kerbrat-Orechiont Comnorakin mon. 15-17. 
La publicación de Langage (1933) fue fundamental para la historia de la connotación porque, y aun carente de la homogeneidad necesaria, supuso la adopción de un conductismo pleno y la distinción entre significados estables, primarios, normales o centrales frente a marginales, metafóricos o transferidos ${ }^{49}$. Después aportó otros valores suplementarios: las connotaciones, que pueden provocar desviaciones del uso normal agregando elementos significativos o incluso restándolos ${ }^{50}$, y las clasificó en tres grupos diferentes ${ }^{51}$; a saber:

- las ciue responden a diferencias según la posición social y regional de los habiantes ${ }^{5 ?}$

- las que dependen de los valores que los propios términos adquieren según el uso social que se hace de ellos ${ }^{53}$;

- y, finalmente, las formas intensivas: exclamaciones, interjecciones, onomatopeyas, habla infantil, etc ${ }^{54}$.

\subsubsection{La comnotación en Hjelmslev: connotación, connotadores, y semióticas} connotativas

Si Bloomfield contribuyó a la confusión terminológica de connotacióndenotación y a esa especie de inversión de sus sentidos técnicos derivados de la lógica moderna, la contribución de Hjelmslev ha sido más de orden conceptual ${ }^{55}$, puesto que intenta partir de la hipótesis que, centrada en la sistematicidad de las lenguas y la homogeneidad de los textos, le permita construir una teoría cuya forma de análisis sea deductiva.

Así, distingue entre semióticas denotativas, de solidaridades unívocas, y semióticas connotativas, en las que a la solidaridad entre formas de contenido y expresión se le añaden otros indicadores. A continuación, los tipos de connotadores, que no difieren mucho de los de Bloomfield, constituyen un inventario aproxi-

"4. L. Bloomfield, Lamguage, pág. 149.

30 Sobre las connotaciones de Bloomfield son interesantes, entre otros: B. Garza Cuarón. Commotación. pp. 168-176; y J. Molino, «Connotation», pp. 9-12.

si Con todo, la clasilicación de Bloomfield no es homogénea. El criterio de los dos primeros grupos es somántico (de hechos significados connotativamente: los niveles de lengua, las realidades valoradas negativamente). El grupo tercero se apoya en el significante: formas que suelen connotar: cf. S. Gutierrez Ordóñez, Sémámića, pág. 74.

52 Cf. L. Bloomfield, Language, pp. 152-154.

5. En loda comunidad existen realidades que por razones culturales (supersticiones, religión, conceptualización social. etc.) poseen una valoración negativa: tales hechos u objetos son ocultados o cvitados dentro de lo posible. Este veto, tal valoración negativa, tiñe también al nombre que los designá y. cono consecuencia, se evila su uso; cf. L. Bloomfield, Language, pág. 155.

5 CT. L. Bloomfield, Lamsuage, pp. 156-157.

55 Una descripeión seria y rigurosia de las ideas de Hjelmslev sobre la connotación puede encontrarse en B. Garza Cuarón, Comnotación, pp. 176-185. 
mativo y alusivo de formas estilísticas diferentes, estilos diferentes (creativo imitativo), estilos axiológicos diversos (de alto o bajo valor), medios diferentes (habla, escritura, gestos...), tonos distintos, idiomas diferentes, etc $^{56}$.

\subsubsection{La connotación en G. Mounin}

Se produce ahora una crítica a las teorías de Bloomfield y Hjelmslev, con las que Mounin trata de entresacar de los varios sentidos que los autores dan a la connotación, aquellos que se pueden considerar realmente lingüísticos ${ }^{57}$. De esta forma, y sin considerar válida la división de la lógica entre semántica, sintaxis y pragmática ${ }^{58}$, propone conservar el epíteto de afectivo para referirse a los rasgos que escapan a la doble articulación y que no participan del carácter discreto de sus unidades ${ }^{59}$.

Junto a ello, con el término connotación distingue varias categorías de hechos:

- selección de formas en varios paradigmas (relaciones entre los signos y sus utilizadores, y otras que se encuentran expresadas en el sistema de la lengua);

- tonalidades enfáticas en la pronunciación (relaciones entre los signos y sus usuarios, que se expresan por medio de una modificación personal de la fonía);

- niveles de lengua y tipos de situación ${ }^{60}$.

Más tarde, propone los tres tipos de teorías que deben aplicarse al análisis riguroso de las formas significativas ${ }^{61}$; a saber:

- la teoría lógica, que intenta descubrir rasgos semánticos pertinentes mediante los cuales estarían construidos los significados; los analiza en Lounsbury, (animales domésticos y vivienda);

- la teoría contextual, que sostiene la hipótesis de que la unidad léxica no tiene sentido por sí misma, sino en el contexto; los estudia en el concepto de sistema de Meillet;

- y, finalmente, la teoría situacional del significado del monema aislado (Bloomfield), basada en el postulado de que el significado es la situación en la cual el hablante enuncia una unidad y la respuesta que provoca en el oyente ${ }^{62}$.

\subsubsection{La connotación en Martinet}

Martinet, por el contrario, distingue entre connotación y denotación tomando en cuenta sólo términos aislados ${ }^{63}$. Por denotación no entiende una mera relación

${ }^{56}$ Cf. L. Hjemislev, Prolegómenos, pp. 161-162.

${ }^{57}$ Cf. G. Mounin, «Léxico, connotaciones y traducción» apud Traducción, pp. 172-199.

${ }^{58}$ Cf. G. Mounin, Traducción, pág. 194.

59 Cf. G. Mounin, Traducción, pág. 185.

6) Cf. G. Mounin, Traducción, pp. 194-195.

${ }^{6}$ Cf. G. Mounin, Semántica, pp. 21-22.

${ }^{62}$ Su opinión final es que estas teorías no se oponen, sino que son complementarias y que el análisis del monema aislado no estaría completo hasta que no se haya estudiado también las connotaciones; cf. G. Mounin, Semántica, pág. 23.

${ }^{63}$ Cf. A. Martinet, «Connotations», pp. 1288-1294. 
substancial o referencial, sino lo que en el valor de un término es común al conjunto de hablantes de una lengua (una definición extensional, entonces). Y, aunque sin relacionar directamente estilo y connotación, piensa que si las palabras evocan, el poeta es quien puede expresarlas al crear contextos que correspondan a la situación original $^{64}$ (caracterizada de esta forma como «valor suplementario», la connotación es definida en «comprensión» 0 «de manera intensiva» $)^{65}$.

\subsubsection{La connotación en Greimas como «sociología del sentido común»}

Una de las preocupaciones mayores de la descripción semántica consiste en la búsqueda de condiciones objetivas que permitan el establecimiento de una isotopía de interpretación, que postule la dimensión connotativa del lenguaje en los universos semióticos individuales y sociales $^{66}$ (pues la lengua no es puramente denotativa, sino multiplana).

Puesto que, de hecho, todo objeto semiótico está dotado de una doble existencia: la forma de ser y de parecer, la dimensión connotativa del lenguaje puede ser postulada tanto en los universos semióticos individuales cuanto en los

${ }^{64}$ Algunos autores han utilizado ambos términos en un sentido muy amplio y no los distinguen. Dicho sentido está constituido por la situación del emisor y la respuesta del receptor. Desde un punto de vista linguístico, los rasgos distintivos son los que permiten el estudio linguiístico, al colocar paralelamente las diferencias discretas de significantes, a pesar de la infinita variación de situaciones. Si lingüísticamente distintivo es aquello que va acompañado de diferencias en la forma del mensaje, parece preferible distinguir un entorno no lingüístico (situación), de uno lingüístico (contexto). La situación consiste en un conjunto de elementos extralingüísticos presentes en la mente de los sujetos o en la realidad física exterior en el momento de la comunicación. El contexto consiste en el conjunto de unidades de la misma naturaleza situadas en proximidad y que por su presencia condicionan la aparición, la forma o la función de los elementos lingüísticos. Lo más importante es la determinación de los contextos creados por el poeta. Martinet establece los siguientes pasos:

- inventario de las unidades y estudio de las restricciones en su distribución: incompatibilidad o, en caso contrario, presencia obligatoria;

- estudio de las variaciones contextuales, cuyo número es necesariamente limitado, pues son combinaciones de longitud finita;

- estudio de las variaciones de las funciones realizadas según la variedad de los contextos tanto si se trata de diferentes funciones sintagmáticas, como si se tratara de diferencias de sentidos.

Al respecto puede consultarse A. Martinet, «Contexto y situación» apud Lingüística, pp. 52-60.

${ }_{65}$ Puede observarse, tal y como afirma C. Kerbrat-Orecchioni, que se produce en Martinet una amalgama entre la perspectiva lógica (que considera la connotación de un concepto como su comprensión) y la perspectiva lingüistica (que concibe la connotación como el conjunto de los componentes connotativos de un término); cf. C. Kerbrat-Orecchioni, Connotación, pp. 16-17.

${ }^{66}$ Efectivamente, Greimas establece distintas zonas de connotación:

- connotaciones que interesan a la sociolingüística: procesos sintagmăticos comparables a las frases infinitas de la gramática transformatoria;

- hechos constitutivos de estilo: palabras, escrituras, gestos, etc.;

- connotaciones constitutivas de una estilística social: estilo en verso o prosa, creador o imitativo, elevado o vulgar.

La descripción de la connotación llevaría a la constitución de tipologías idiolectales. Se trata de parangonar los hechos lingǘsticos con un sistema de juicios sociales que conduce a una personología social; cf. A. J. Greimas, Sentido, pp. 105-107. 
sociales. En los primeros, la lengua sirve para integrar al hombre en su propia sociedad ${ }^{67}$; en los segundos, la connotación instala un espacio semiótico exterior poblado de objetos culturales opacos, comparables al mundo de las cosas.

De esta forma, la connotación abarca más campos: lo sociológico, ideológico, mítico. psicológico, antropológico, etc ${ }^{1 x}$.

\subsubsection{La connotación en Pottier}

La conciencia clara de que entre los significantes y la realidad extralinguística está el mundo de los conceptos ha obligado a la distinción entre el significado como forma del contenido y los conceptos, en cuanto sustancia de contenido extralingüístico. Por ello, y con la finalidad de estructurar la realidad, el hombre ha ido creando conjuntos a través de la lengua (recuérdese el conjunto nocional, universal y amorfo, tal y como expusiera Saussure, igual para todas !as lenguas; y el campo lexical, considerado como la capacidad que tiene una lengua para estructurar el conjunto nocional). En este proceso de estructuración linguística, el campo lexical ha organizado la realidad extralinguística en dos grandes grupos: aquél que presenta un significado relativo o gramatical y, en contraposición, el que presenta un significado absoluto, designativo o predicativo. El primero de ellos engloba a unidades poco numerosas y muy sistemáticas (los gramemas), frente al segundo, que acoge a los lexemas, unidades pertenecientes a una clase débilmente finita y socialmente inestable ${ }^{69}$.

Frente a la semántica esquemática y a la semántica global ${ }^{70}$, Pottier propone una semántica analítica que se ocupa del análisis en semas o rasgos mínimos de significación.

Estos semas pueden ser de dos tipos: descriptivos y aplicativos, estando el semantema constituido por el conjunto de semas específicos en un conjunto dado, y por el conjunto de semas genéricos del mismo (clasema $)^{71}$. Finalmente,

67 Esto se produce mediante una doble taxonomía:

- Primera taxonomía: articulación de la comunidad lingüística en clases y subclases; namifiesta cl parecer de la sociedal.

- Segunda laxonomía: tipología social de los individuos; sirve para una psicología de lo colidiano.

Cr. A. J. Greimas, Senido, pág. 110.

(16 Las ideas generales de Greinas sobre la connotación pueden encontrarse en A. J. Greinals, «Para unal sociología del sentido común» apud Sentido, pp. 101-1 I1. También es interesunte la explicación de su teoría en B. Garza Cuarón, Connotación, pp. 189-191.

69) La explicación de su teoría puede verse en B. Pottier, «La estructuración semántica» apud Presentarión, pp. 66-124; y en Filologia, pp. 93 y ss.

70) Pottier mantiene la existencia de tres niveles de análisis semántico. Junto a la somámica amalin a distingue la somántica esquemática, que estudia los esquemas de entendimiento de las unidades de enunciacion; y la semántica global, que se ocupa de la estructuración natrativa do un texto cerracto; cl. B. Pottier, «la sustancia del significado» apud Lingüistica, pp. $61-106$.

71 Además de la estructuración codificada que procede del funcionamiento sintáclico, se puede hace una estrurtración semántica del significado, expresada por algunas clases nocionales. El chasema. precisamente, es el conjunto de las características de clase, tales como la animación. la continaidad o la lan-

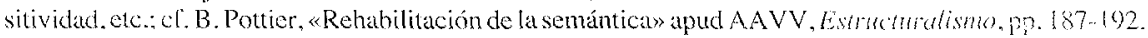


ef vimema representa la parte connotativa del semema que, al depender de las experiencias socioculturales, es inestable ${ }^{72}$. Puede ser una connotación espontánea, analógica (establecida socioculturalmente), contextual (cuando la connotatción individual no ha tenido éxito y es propia de un solo autor), etc.

\subsubsection{La comnotación en L. J. Prieto}

Pitieto ${ }^{73}$ usa el término connotación para referirse al estilo que conlleva todo tipo de mensaje, por lo que viene a ser una segunda indicación que proviene de la elección entre diferentes semas y de la combinación de las formas resultantes.

En este sentido, la connotación hace referencia a un primer sistema de intercomprensión que es la concepción denotativa de la operación y, en resumidas cuentas, junto a la denotación, constituye otra manera de concebir el objeto.

\subsection{Otros usos de la connotación}

- Rey-Debove utiliza la expresión connotation antonymique para estudiar la inserción de referencias literarias en textos literarios.

- J. Schön ${ }^{75}$ considera que existe una interdependencia entre la denotación y la connotación y que el proceso connotativo (con un sentido cercano al creativo) lleva a la disociación de las dos caras del signo.

- Gary-Prieur ${ }^{76}$ intenta clasificar los fenómenos que cubren el término connotación frente a su opuesto denotación, mostrando su preferencia por el análisis de la forma en que puede usarse el sentido de connotación en cuanto redes significativas construidas por el texto.

- Eco ${ }^{77}$ vincula la significación emotiva o connotativa con el receptor del mensaje ${ }^{73}$.

- C. Kerbrat-Orecchioni ${ }^{7 /}$ sostiene que frente al sentido denotativo, que interviene en el mecanismo referencial entrando en relación con un objeto extralingǘstico durante los procesos onomasiológicos (denominación) y

72 De hecho, la dilcrente conceptualización que los individuos tienen de las cosas es la que obiga a distinguir los rasgos generales de los individuales. Los primeros son los aspectos generales, básicos y válidos que constituyen la denotación y los segundos. las diferentes conceptualizaciones que acompañan? a los conceptos y dan a la unidad léxicat un sentido diferente.

7.3 Cl. I.. J. Prieto, «Langue», pp. 5-24.

${ }^{7}$ Cl. J. Rey-Debove, «Notes», pp. 90-95.

75 Cl. I. Schön, «Fonction», pp. 106 y ss.

76 Cf. M. N. Gary-Prieur, «Connotation», pp. 96-107.

7 Para Eco, el lenguaje literario es un sistema semiótico secundario connotativo o emotivo porclise utiliza como signifucante un sistema semánico primario. que es el sistema lingüístico: cf. U. Eco. Obra, pág. 106.

* A igual que ocurriera con Mattinet, intenta conciliar las perspectivas lógica y finguística llegando a aloptar la concepción extcnsiva de la connotación propia de los lógicos y, al mismo tiempo, le precupacion de ios lingüistas por definir la significación sin subordinarla al referente, lo que, como reconoce C. Kerbrat-Orechioni, Comolación, pág. 17, le lleva a caer en una auténtiea aporía.

".. C. Kerbrat-Orecchioni, Comnofación. pág. 19. 
semasiológico (identificación del referente), el sentido connotativo consiste en el conjunto de informaciones subsidiarias que se trasmiten.

- Riffaterre ${ }^{80}$ considera que la connotación responde a la adherencia que los signos conservan como recuerdo de sus empleos anteriores.

- Antal ${ }^{81}$ finalmente sostiene que el lenguaje es un medio de comunicación humano en el que la emoción es el denotatum del mismo.

Una concepción denotativa supone ignorar la constante generación de sentido para acentuar la ruptura entre palabra y realidad. Podemos, pues, entender un texto a partir de la connotación porque se encuentra muy unida a las posibilidades creativas del lenguaje.

\section{CONCLUSIÓN Y PROPUESTA METODOLÓGICA}

Todas estas reflexiones ponen de relieve el hecho de que es necesario trascender el simple significado denotativo de cada lexema para llegar al significado emotivo del discurso, puesto que el estudio del funcionamiento connotativo de la significación es un complemento tan indispensable para el análisis semántico que obliga a una reformulación en términos más complejos del problema de la manifestación del sentido en el marco de la teoría semántica global. De ahí que lo que proponemos sea otro nivel de acercamiento semántico al texto, más cercano a los postulados de una semántica estilística ${ }^{82}$, pero no por ello menos oportuno e interesante.

En el modelo dialéctico de análisis semántico que postulamos (ya sea de un texto o de un campo léxico) puede distinguirse tres partes:

- una primera parte descriptiva, que consiste en el análisis de los significados denotativos de los lexemas que componen el campo léxico que pretendamos estudiar-semántica estructural-.

- otra parte explicativa, que pone en relación el texto con los recursos utilizados por el creador para transmitir un mensaje -semántica sintomática ${ }^{8.3}$.

- y, finalmente, una parte valorativa, que conecta la creación artística con una realidad foránea a ella-semántica hermenéutica-.

${ }^{80}$ Cf. M. Riffaterre, Ensayos, pág. 324.

81 Cf. L. Antal, Content, pp. 58-61.

${ }^{82}$ El vocabulario o el léxico tienen gran importancia como criterio de caracterización de una lengua. La tarea y la misión de la estilística consiste en buscar cuáles son los tipos expresivos que en un periodo dado sirven para traducir los movimientos del pensamiento y del sentimiento de los hablantes, los procedimientos por medio de los cuales produce la lengua la emoción, etc.; cf. Ch. Bally, Lenguaje, pp. 90 y ss.

${ }^{83}$ La especificidad del significado emotivo o de la connotación no ha de buscarse en las clases de objetos connotados. Al igual que en la significación primaria, todo puede ser significado connotativamente, pues no existe a priori contenidos connotativos y contenidos denotativos, sino sólo informaciones o sustancias de contenido susceptibles de ser informadas o actualizadas en el texto bien denotativa, bien connotativamente; cf. J. A. Martínez, Propiedades, pág. 203. 
Para que las ideas organizadas del autor estén en el ámbito de la literatura, y no en otro, es necesario que éste utilice una serie de recursos que den a su creación un valor artístico. El modelo que proponemos debe explicar, precisamente, estos recursos y analizar la diversidad de los significantes a través de los cuales se actualizan en el habla los significados de la connotación ${ }^{84}$. Para ello, el esquema hjelmsleviano que opone el lenguaje de la denotación (caracterizado por la asociación de los dos planos de la expresión y del contenido) al de la connotación (que sería un metalenguaje formado por los signos del sistema denotado), ampliamente aceptado por los lingüistas, no explica adecuadamente la naturaleza del metalenguaje ${ }^{85}$ ni la totalidad de los mecanismos connotativos. Los significantes de la connotación pueden ser además otra cosa que un signo denotativo, como por ejemplo una construcción vacía de sentido denotativo, un significante léxico, etc.; por ello, la idea de Hjelmslev debe formularse de manera diferente: «los códigos connotativos presuponen los códigos denotativos» y los significantes de la connotación como una «configuración sociocultural específica, irreductible a cualquier denotación ${ }^{86}$. Ello debe ser explicado en el interior del modelo dialéctico que proponemos.

Y para facilitar la comprensión y aplicación del planteamiento expuesto en nuestro trabajo, nos proponemos definir ahora dos nociones preliminares de gran interés: el sentido y el análisis crítico.

Desde una perspectiva lingüística, el sentido se concibe como una reconstitución por parte del destinatario del mensaje textual elaborado por el emisor, comprensión explícita de los significados denotativos del texto objeto de análisis ${ }^{87}$.

${ }^{84}$ De hecho, como reconoce C. Kerbrat-Orecchioni, debe aceptarse que la connotación, así como tiene sus significados específicos que nunca fueron cuestionados por la tradición lingüística posthjelmsleviana, también tiene sus significantes propios que deben ser considerados en una teoría general de la connotación; cf. C. Kerbrat-Orecchioni, Connotación, pp. 27 y ss.

${ }^{85}$ Efectivamente, un discurso que hable del lenguaje no es por ello un «lenguaje cuyo contenido sea ya un lenguaje»; cf. C. Kerbrat-Orecchioni, Connotación, pág. 90; además, una crítica a las ideas de Hjelmslev sobre la connotación puede verse en M. A. Bonfantini, «Connotación», pp. 150-151.

${ }^{86}$ Cf. C. Kerbrat-Orecchioni, Connotación, pág. 95.

${ }^{87}$ En una acepción más amplia que también se le atribuye, esta noción rebasa con mucho la relativamente restringida de la descodificación semántica de un texto y abarca todo mensaje dirigido a un receptor; cf. C. Reis, Análisis, pp. 15 y ss.

En una crítica a los conceptos chomskyanos de competencia y actuación, señala Wunderlich, Pragmatik, pág. 19, que la pragmática no se ha de equiparar a actuación sino que el concepto de competencia se tiene que ampliar hasta el punto que también contenga el componente de competencia pragmática (capacidad de los hablantes y oyentes para comprenderse). Apoyándose en J. Habermas, Theorie, pp. 101141, Wunderlich llama a esta competencia pragmática competencia comunicativa.

W. Abrahan, Theory, amplía el concepto chomskyano de competencia, señalando que ésta no sólo decide sobre la gramaticalidad, sino también sobre las formas de manifestación de la actividad verbal que son típicas para determinados sectores de hablantes de una lengua.

Por su parte, J. W. Oller, "Transformational”, pp. 504-507, afirma que la distinción original entre competencia y actuación expuesta por Chomsky se ha deteriorado por la equiparación de competencia al conocimiento del hablante ideal de su lengua, dejando sin explicar el empleo real. Por ello plantea la necesidad de una teoría adecuada de la competencia (cf. J. W. Oller, "Transformational", pág. 506).

Sobre las diferentes interpretaciones de la componente tacticoretórica y hermenéutica puede consultarse además S. J. Schmidt, Teoría, pp. 33-34; B. Schlieben-Lange, Pragmática, pp. 60-65, etc. 
Aś, ef sento de un elemento del texto es su posibilidad de crar ch conelación wh otros clementos de ese texto, o con el discurso en su lotalidad.

Wo siscole lo mismo con el análisis crítico, que es diterente según la personaluad cel cútico. Por análisis crítico se entiende ante todo, por una cuestión de conerencia ctinologica, la descomposición de un todo en sus clementos constituivos. Siendo este todo un texto de variable extensión, el análisis se concebirá entonces como una actitud descriptiva de los significados denotativos del texto o campo estudiado que culminará con una expicación de los signilicados connohativos en la que el estudioso deberá ceñirse a una toma de posición acional, a una actitud objetivamente cientifica que debe predominar sobre la subje ividad del sujeto receptor ${ }^{\mathrm{p}}$.

Estas a frmaciones no pueden inculcar la idea de que una descripción y expicacion anditica se someten invariablemente a las mismas reglas. De hecho, é csedioso no consigue evitar a veces la subjetividad; la circunstancia de concretam forzosamente una determinada opción metodológica deja suponer una no s sulada preferencia por determinadas facetas críticas. Sin embargo, porgav pensanos que es necesario abordar el significado total de un campo a un îve gre sipere la sola descripción lingüística de los significados denotativos. perilamos la idea de que cualquier estudio del significado que se pretenda satistactorio debe pasat de una fase descriptiva a otra predominantemente explicativadel sigrilicado emotivo, regida por unos principios melodológicos lo más gobetivo oosibles".

Como sabemos, la teoría semántica se plantea el problema genera! de la legibilied de los textos y trata de establecer un inventario de los procedimientos de saschpción. El texto, para tener un sentido, debe tener un todo significati vo. y or aso se presenta como una estructura semántica simple que debe ser cxpiraca anotén sobre la base de sus significados emotivos (la connotación).

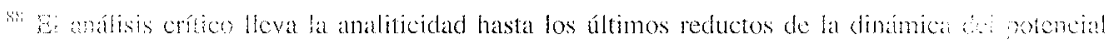
cretivo humaro, signico comunicativo, preparando con éxito la súntesis complemertarial que pondrá de

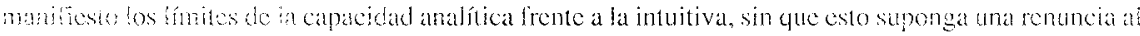
mabijo reflexivo, como puede comprenderse: of. E. R. Trives. Semántici. pp. $185-188$.

is Fintinente y sobre los datos obtenidos de antemano. se abre un proceso interpretativo fundamen-

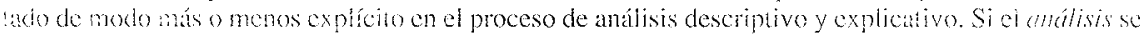

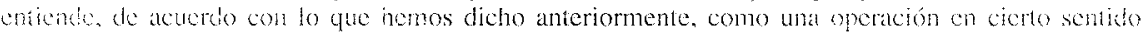

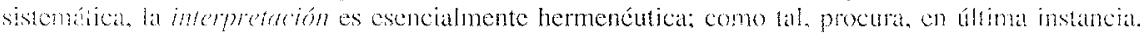
concrater ma penetración que se propone pasar de la mera deseripción lingüistica y explicación literaria a la mierpretación tolal en un modelo globalizante. Esto quere decir que la síntesis interpretaliva del esterdie diatécico ded signilicado se basa fundamentalmente en unal noción teóneal de considerable

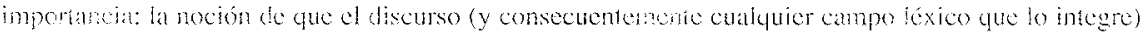
funciona como un signo extéf ico dotaro de signilieados denchativos y connotativos caya relación con los

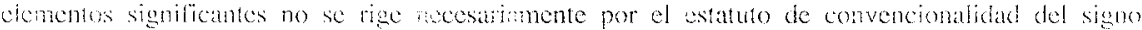
linet istico. Por eso ha interpretación se dirige de modo prioritario al descubrimiento de fos seatidos

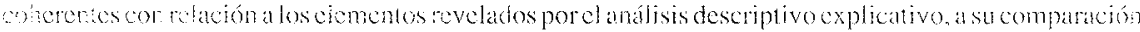

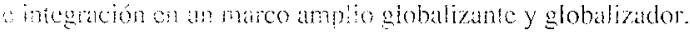

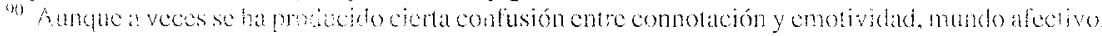

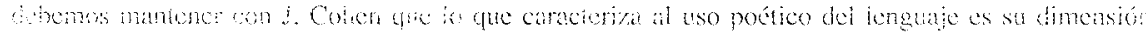

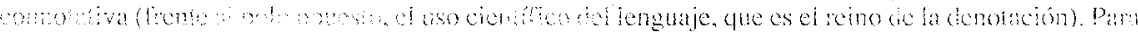


En el pantamiento que proponemos debemos ser lo mas objetivos posible, sin cacr de llcno en lo que sería un análisis estilístico del texto, más cercano a las

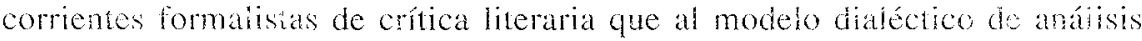
semántico que proponemos; por tanto, debe comprenderse que nuestro proncisito es únicamente acercarnos a la estructura semántica que pueda presentai un texto (a través de las relaciones sémicas entre las unidades que lo componer o dei funcionamiento de las mismas en el interior de los diversos campos iex ius on los que se pueda estructurar el texto analizado) desde varias perspectivas a sistica y literaria, estructural y sintomática, denotativa y connotativa), cor an de dar posibilidades mayores de análisis a la teoría semántica, y facilia a nterpretación comparativa de los resultados de ambos acercamicntos, sencendo ba inportancia del significado connotativo junto al objetivo, denotativa aforencis.

En síntesis, y con el fin de precisar lo anteriormente expresto ci paragna de explicación de un texto debe basarse en los siguientes punios:

- el texto está formado por una significación denotativa y om emoria. Junto a la descripción de los significados denotativos proponemos la expicacion de los significados emotivos adoptando un modelo de semántica sintomática:

- el uso poético del lenguaje se basa en la expresión de unas ideas a irivés de una serie de imágenes;

- el estudio de estas imágenes nos permite llegar al significado emotivo a ia comprensión de las connotaciones usadas por el autor para actuabizat en el toxto una serie de significados dirigidos principalmente no al animus sino a anima intelectiva y que son, en resumidas cuentas, la expresión inmanente de la trascendencia del lenguaje sujeto.

Partiendo de estas puntualizaciones, la elaboración de un modelo semántco que nos permita explicar el significado emotivo a través de las imágenes debe tener muy presente el hecho de que el poeta, tomando como punto se parida do su peculiar visión del mundo, ha realizado una selección dentro del conjunto léxico de una lengua, cuya plasmación en un texto presenta el predominio do diversos campos nocionales que constituyen su sistema léxico, un sistema que debe ser ei primer punto sobre el que debe girar nuestra explicación"

Por ello, debemos establecer cómo este sistema léxico se plasma en ana serio de construcciones imaginativas (imágenes), que representan el estado incrion

estc alutor, la connotación es la repercusión significativa de un signo en el nundo de la afectividudi sis denotación designa la resptesta cognitiva y la connotación la respuesta afectiva desencadenads por dos expresiones diferentes del mismo objetom. Otra cosa bien distinta es la explicación de las distinats comnotaciones que puedan conformar el significado emolivo de un campo léxico, por ejomplo: el 1 . Cohen, Litructura. pig. 201.

") Como afrimal propio Alinei, Lessico, pp. 69 y ss., los téminos de en dominio léxico no perienceen a la misma categoría gramatical: está integrado por varios sistemas siempre en reliteión con ston dominio centan. Cualquera que sea la organizatción jerárquica de los rasgos, se pueden reducir fodos los semantemas ar un dominio a un número linito de sistemas; sobre cstals y was ideas de M. Alinej puede

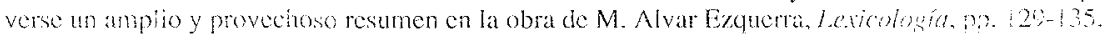


del poeta en el momento de la creación, precisando su significado gracias a la utilización de las diferentes fuentes lexicográficas de las que dispongamos, contemporáneas al autor del texto que pretendamos analizar. Dicho de otra forma, se trata de precisar los semas específicos de una serie de sememas connotados manifestados léxicamente por estas imágenes (que son los que en un paso posterior nos permitirán estudiar los diferentes sememas connotados $)^{92}$.

De esta manera, la explicación sincrónica de las imágenes (que debe ser una síntesis de la evolución de los significados de las mismas) nos habrá permitido establecer los distintos sememas (y sus correspondientes semas) connotados, que conformarán la estructura semántica de estos significados emotivos.

Ello justifica que nuestro modelo deba asimismo explicar la estructuración que siguen estas imágenes, estructuración basada en una relación binaria entre dos elementos que tienen algún rasgo en común. Estudiaremos en este punto la naturaleza de la semejanza entre estos elementos, así como las construcciones imaginativas con las que se expresan: símbolos, emblemas, sinestesias, desplazamientos calificativos, visiones, etc.

A continuación proponemos un análisis formal de las imágenes, es decir, del modo en que éstas aparecen formuladas, con el propósito de confirmar que se trata de signos literarios y justificar, por tanto, una vez más la explicación sintomática que adoptamos ${ }^{93}$.

Todo ello nos lleva, inevitablemente, a un esbozo de comentario semántico en el que debe explicarse, ya de forma global, el significado emotivo del texto objeto de estudio e investigación ${ }^{94}$.

Después debe integrarse en la microestructura léxica establecida el resto de los semantemas que componen el léxico objeto de análisis y que conforman lo que llamamos macroestructura semántica.

92 Efectivamente, podemos decir que las distintas imágenes son las manifestaciones léxicas de una serie de sememas connotados, todos ellos puestos de relieve por una serie de semas que el estudio lexicográfico nos ha permitido precisar.

${ }_{93}^{3}$ El estudio formal de las imágenes sería casi innecesario de acuerdo con el planteamiento que hemos señalado; por ello, conviene recordar que lo que proponemos no es, ni mucho menos, un estudio formal del texto. Cuando Jakobson afirmó, hace unos cincuenta años, que el objeto de la literatura era la literariedad, esta frase llevó a muchos engaños y a muchas malas interpretaciones. Según nos dice Todorov (cf. T. Todorov, "Categorías" apud R. Barthes, Análisis, pág. 155), Jakobson no quería substituir el enfoque trascendente (psicológico, sociológico, o filosófico), que reinaba hasta entonces, por un estudio inmanente. Uno nunca se limita a la descripción de una sola obra. Sería mejor decir que, en lugar de proyectar la obra sobre otro tipo de discurso, se la proyecta sobre el discurso literario. Se estudia, no la obra, sino las virtualidades del discurso literario que la han hecho posible.

Estas consideraciones de Todorov, nos permiten introducir, sólo a título enunciativo, algunas consideraciones sobre la forma de las imágenes con el único propósito que hemos señalado.

94 Una forma de llevarlo a cabo, por ejemplo, consiste en dividir el texto en partes temáticas y realizar varias explicaciones (superficial y profunda) de cada una de ellas, hasta llegar a la clave temática emotiva del texto. 
Pottier ${ }^{95}$ propone no partir nunca del diccionario para establecer el corpus de un campo, porque le falta la homogeneidad indispensable, y no representa el sistema de una lengua funcional sino los datos de una lengua histórica. Por eso, como señala Mounín, las definiciones no son productos de procedimientos lingüísticos, sino productos de procedimientos lógicos, y las definiciones lógicas no siempre coinciden con los usos lingüísticos ${ }^{96 .}$ Las dificultades para aceptar la estructuración del léxico siguiendo las definiciones de los diccionarios consiste en que tales definiciones no han sido formuladas a partir de un léxico cuya estructura haya sido puesta previamente en evidencia. Los diccionarios tradicionales nos dan indiscriminadamente y sin $\operatorname{aclarar}^{97}$ :

— formas que sólo representan el archisemema del conjunto al que pertenece el término definido;

— formas que poseen además rasgos propios que no pertenecen al término definido;

- o formas que representan la diferencia específica, lo cual estaría bien si se hiciera ver este carácter y se aludiese a la genérica.

Sin embargo, debemos coincidir con $\mathrm{M}$. Trapero ${ }^{98}$ en que olvidar el diccionario y elegir el vocabulario guiándose sólo de la propia intuición es menos seguro todavía. La razón estriba, como afirma $\mathrm{R}$. Trujillo ${ }^{99}$, en que el diccionario tradicional, a falta de otras fuentes más rigurosas, sigue siendo la base más objetiva que se puede tomar como punto de partida en el análisis semántico de un campo léxico, y en la selección del vocabulario. Por ello proponemos partir, por ejemplo, del diccionario de Casares ${ }^{100}$. Cierto es que un diccionario precisamente por su ordenación alfabética es, como afirma Baldinger ${ }^{101}$, una macroestructura formal; ahora bien, también puede ser concebido como una macroestructura conceptual todo diccionario ideológico que se ordena sobre la base de conceptos. Toda palabra está, pues, rodeada por una red de asociaciones que la conectan con otros términos de su misma lengua, organizándose en campos. Nuestra tarea consiste en seleccionar, de entre todos esos campos ideológicos que constituyen el universo semántico de cualquier lengua, aquellos que puedan identificarse con esos otros que componen los macrocampos que dominen la sustancia semántica del texto.

${ }^{95}$ Cf. B. Pottier, Presentación, pág. 239.

${ }^{96}$ El problema consiste en saber si las definiciones contienen una enumeración más rigurosa de los rasgos distintivos que permita una delimitación clara de un campo, pues la totalidad de las relaciones existentes en el mundo no lingüístico no están perfectamente lexicalizadas; cf. G. Mounin, Semántica,pp. 128 y ss.

${ }_{97}$ Cf. R. Trujillo, Campo, pág. 408.

98 M. Trapero, 'Deporte', pág. 24.

${ }^{99}$ R. Trujillo, Campo, pág. 515.

${ }^{100} \mathrm{~J}$, Casares, Diccionario ideológico de la lengua española, Gustavo Gili, Barcelona, 1988.

${ }^{101} \mathrm{~K}$. Baldinger, Teoría, pág. 119. El diccionario alfabético presenta el vocabulario en macroestructura formal: las palabras se clasifican según su proximidad grafemática, pero no hay que olvidar que el alfabeto da sólo una macroestructura formal y, seguramente, no la más interesante. 
Phalmente, so trata de explicar cada una de las connotaciones de los sememas analyabs, en sus distintas formas de manifestación léxica y, basándonos en este análiss, ssirdiar ios macrocampos léxicos emotivos resultantes seleccionando los sernantonas que pueden incluirse en él y justificancio los semas que nos pemiten á selección ${ }^{102}$. Y así, de esta foma, habremos concluido las connotaciohes jnerentes al semema estudiado, expresadas formalmente por una serie de lexas qu conshayen un auténtico sistema equiparable, por su conerencia interna y bopendencias, a cualquier universo que clasifique ideológicamente los clemenios; cons i hos de la realidad extralinguística, llegando a un auténtico sistema, máso nonos abietio, de significaciones secundarias que conforman el campo léxico connotativo analizado, un campo organizado, meditado, y basado en las connotaciones alectivo-vatorativas que constituyen un auténtico universo ideológico.

Es posibs que ?as connotaciones analizadas manifiesten una doble procedencia: connolaciones típicas, integradas en una tradición histórico-literaria recogida por a aron: y connotaciones prototípicas de éste, derivadas de sus intimas vivenciss y que pueden llegar a convertirse en auténticos simbolos. Por ello, y con ei to precivar la importancia de la aportación del autor analizado, e: siguieno paso puede consistir en un análisis diacrónico ${ }^{10 \%}$ de las distintas susancias semanicas que conceptualizan los sememas connotados ${ }^{10.4}$. Comenzaremos exuchando la evolución diacrónica de aquellas lexías que constituyen las Gituros substancias semánticas o esferas de aplicación ${ }^{105}$ en las que se han actuatrabo los sememas comotados a lo largo de la historia, utilizando para ello bos distintos diccionarios de símbolos y mitos que nos permiten entender la

10? Pe hecho, ho especílico de un campo léxico es su carácter de sistena significante de un segundo siscona significado de indole subjetiva y de difícil conceptualización. soportado por açuél en virtud de una asociación alectivo-emotiva: cl. M. J. Fernández Leboráns, Luz, pás. 246.

10.3 Janto al anúlisis sistemático y sincrónico propuesto, el signilicado emolivo también puede ser estudiado analítica diacrónica. externamente. Lejos de excluirse hay un doble deteminimo en el que las causas cxicmals e internas se complenentan pues, sin lugar a dudas, la palabral es resultado de an impacto opresion de la historia sobre el sistemat cf. S. Ullmann, Lenguaje, pp. 60)-66. Debe entenderse, finaimente, que, aungue itanemos a este estudio análisis diacrónico (por unat razón metodológica), se taala de unat búnqueda a secuperación de la sincronáa histórica en cuanto que constiluye referencias por el quehacer poútico del athor analizado (fa diacronáa, en rigor académico, scría el cstudio a través del liempo de diversals secciones sistemáticas conparándolas; es decir, la comparación entre sincronías bistóricas diversits.

19. Hablamos aluoal on Giminos glosemáticos y tratumos de plantear el probiema en un sentido onomuatológice (campos onomasiológicos o sinonímicos), to cual cremos yue es apropiado en un planlcimaiento diacrónico.

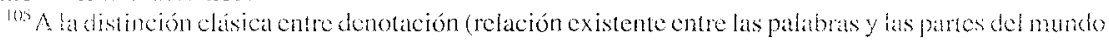
extrat ngeírifor a las chlales designa) y connotación (címulo de componentes de significado que añaden an valor combalisto a la funcion de designación básica) añadimos a propuesta de Zgusta de estura de aplicacion de la mabrab que distinta de la connotación, pues se trata de las posibilibiades individuacs de esia palabra. Su uso en un dominio y no en otro a veces está narcado may tijantenente. El estudio diacronico de estas esferas de aplicakión que actualizan los distintos sememas connotados a wavés de una

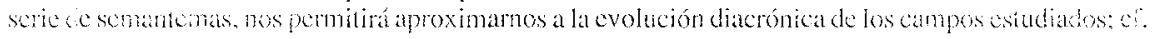
L. Zgusta. Manual. pp. 27 y ss. 
fundamentación histórico-literaria de las distintas substancias senánicas do los diferentes campos léxicos connotativos resultantes.

Sin embargo, el análisis semántico diacrónico no debe quedare exclusiva nene cn esta explicación, sino que debe estudiar la evolución del campo, su amplación a restriccion a lo largo de la historia. Para ello, y sobre las tuentes lexicogreficar disponibles, debemos iocalizar la acepción o el uso emotivo de los gistatos semantemas quic manifiestan léxicamente las esteras de aplicación estudiadas anteriomente, y establecer las distintas genealogías de los sistemas restibates do ia evolución de estass esferas de aplicación. Ello nos daría los disintos sisenas cmparentados genealógicamente de los macrocampos léxicos estudiacios.

Finalmente, el estudio diacrónico podría concluir con la explicucićn de los distintos tipos ce mutación semántica que se han producido, una vez efectuada a confrontación de los sistemas cronológicamente sucesivos.

Se traka de un análisis semántico diacrónico basado en of mundo del opico literario y su cvolución, que nos permitirá explicar cuál ha side a traycoinia poética de estos significados a lo largo de la historia literaria.

Consiste, por tanto, en un estudio, en cierto modo, lexicogrifico, sobe ha base de diccionarios esotéricos, de mitos, de símbolos y de tradicioncs poétcas, que nos permitirá entender la fundamentación histórico-literaria de los significados emotivos estudiados.

En síntesis, los pasos de la explicación de los signilicados emotives dentro del modelo de semántica sintomática son los siguientes:

- estudio del dominio léxico;

- plasmación del dominio léxico en imágenes:

- el significado emotivo de estas imágenes:

- La esinctura y la forma de las mismas;

- explicación global del significado emotivo de los microcampos íxicos establecidos;

- explicación de las connotaciones de los sememas estudiados a partir del análisis de sus diferentes lormas de manifestación léxica;

- estudio de los macrocampos léxicos emotivos resultantes. seleccionando sus semantemás y los semas que nos permiten la selección:

- anál sis genealógico de los distintos sistemas procedentes de ta evonución de la sustancia semántica que conforma los macrocampos léxicos emotivos;

- y, Gramente, la explicación de los diferentes tipos de mutación semánica que se han producido.

De esta manera. el modelo de semántica sintomática nos habrá pernivide entender el hex to a partir de la connotación, ampliando las perspectivas de ha toria

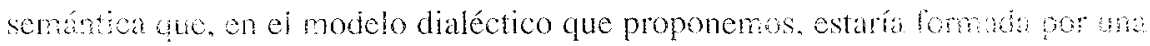
senán ien linguística que describiría la estructuma semintea de bs sig ificados denotativos y por una semántica sintomática, encargada de la explicación do a a estructura semánlica de los significados connotativos del mismo texto. 


\section{REFERENCIAS BIBLIOGRÁFICAS}

AAVV, Estructuralismo y lingüística, Nueva Visión, Buenos Aires, 1971.

AAVV, Exégesis y hermenéutica, Ed. Cristiandad, Madrid, 1976.

ABRAHAM, W., A Theory of Structural Semantics, Mouton, La Haya-París, 1966.

ALINEI, M., La struttura del lessico, Il Mulino, Bolonia, 1974.

ANTAL, L., Content, Meaning and Understanding, Mouton, París, 1961.

BALDINGER, K., Teoría semántica I: Hacia una semántica moderna, Alcalá, Masdrid, 1970.

BALLY, Ch., El lenguaje y la vida, Losada, Buenos Aires, 1967 [1926].

BARTHES, R., La semiología, Tiempo contemporáneo, Buenos Aires, 1970.

BARTHES, R., Análisis estructural del relato, Comunicación, Buenos Aires, 1982.

BEAUCHAMP, P., «La búsqueda del sentido» apud AAVV, Hermenéutica, pp. 53-58.

BLACK, M., Modelos y metáforas, Gredos, Madrid, 1966.

BLOOMFIELD, L., Language, Allen y Unwin, Londres, 1976 [1933].

BONFANTINI, M. A., «Sobre la connotación», ELUA, n 4 (1987), pp. 149-158.

BREKLE, H., Sémantique, A. Colin, Paris, 1973.

BUNGE, M., Antología semántica, Nueva Visión, Buenos Aires, 1960.

CASTILLA DEL PINO, C., Introducción a la hermenéutica del lenguaje, Península, Barcelona, 1972.

CERDA, R., Lingüistica hoy, Teide, Barcelona, 1979.

COHEN, J., Estructura del lenguaje poético, Gredos, Madrid, 1970.

COLLADO, J. A., Fundamentos de lingüística general, Gredos, Madrid, 1978.

COVEZ, M., Los estructuralistas, Amorrortu, Buenos Aires, 1972.

DAIX, P., Claves del estructuralismo, Calden, Buenos Aires, 1969.

DUCROT, O., El estructuralismo en lingüística, Losada, Buenos Aires, 1975.

ECO, U., Signos, Labor, Barcelona, 1976.

ECO, U., Obra abierta, Seix Barral, Barcelona, 1965.

ECO, U., La estructura ausente, Lumen, Buenos Aires, 1981.

FERNÁNDEZ GONZÁLEZ, A. et alii, Introducción a la semántica, Cátedra, Madrid, 1977.

FERNÁNDEZ LEBORÁNS, M. J., Luz y oscuridad en la mística, Planeta, Madrid, 1978.

GARY-PRIEUR, M. N., «La notion de connotation», Li, 4 (1971), pp. 96-107.

GARZA CUARÓN, B., La connotación: problemas del significado, El Colegio de México, México, 1978.

GERMAIN, C., La semántica funcional, Gredos, Madrid, 1986.

GILSON, E., Lingüística y filosofía, Gredos, Madrid, 1974.

GREIMAS, A. J., En torno al sentido, Fragua, Madrid, 1973.

GREIMAS, A. J., Semántica estructural, Gredos, Madrid, 1973.

GUIRAUD, P., La estilística, Nova, Buenos Aires, 1967.

GUTIÉRREZ ORDÓÑEZ, S., Introducción a la semántica funcional, Síntesis, Madrid, 1989.

HABERMAS, J., Theorie der Gesellschaft oder Sozialtecnologie, Francfort, 1971.

HJELMSLEV, L., Prolegómenos a una teoría del lenguaje, Gredos, Madrid, 1969 [1943].

JAKOBSON, R., Ensayos de lingüística general, Seix Barral, Barcelona, 1975 [1960].

JIMÉNEZ RUIZ, J. L., «Notas para una teoría de la explicación del significado connotativo», Analecta Malacitana, Vol. IX, 2 (1986), pp. 407-418.

JIMÉNEZ RUIZ, J. L., «La Rima III de Bécquer: descripción, explicación e interpretación», Boletín de la Asociación Europea de Profesores de Español, Año XVIII, n² $34-$ 35 (1986), pp. 159-179.

JIMÉNEZ RUIZ, J. L., «Hacia un modelo teórico que describa la estructura semántica de los significados denotativos», ELUA, nำ (1991), pp. 61-97. 
JIMÉNEZ RUIZ, J. L., «La interpretación dialéctica del significado», Analecta Malacitana, Vol. XIV, 2 (1991), pp. 315-333.

KANY, Ch. E., Semántica hispanoamericana, Aguilar, Madrid, 1962.

KAPLAN, A., «Definición y especificación del significado» apud BUNGE, M., Semántica, pp. 76-85.

LÁZARO CARRETER, F., Estudios de lingüística, Crítica, Barcelona, 1980.

LLEDÓ, E., Filosofía y lenguaje, Ariel, Barcelona, 1970.

LURIA, A. R., Conciencia y lenguaje, Pablo del Río editor, Madrid, 1980

LYONS, J., Introducción en la lingüística teórica, Teide, Barcelona, 1981.

MARTINET, A., La lingüística, Anagrama, Barcelona, 1972.

MARTINET, A., «Connotations, poésie et culture» apud To Honor Roman Jakobson, II, Mouton, La Haya-París, 1967, pp. 1288-1294.

MARTÍnEZ, J. A., Propiedades del lenguaje poético, Archivum, Oviedo, 1975.

MEIX IZQUIERDO, F., La dialéctica del significado lingüístico, Universidad de Salamanca, Salamanca, 1982.

MOLINO, J., «La connotation», LL, 7 (1971), pp. 9-12.

MOULOUD, N., «Significación, lenguaje y estructura» apud AAVV, Estructuralismo, pp. 43-70.

MOUNIN, G., Los problemas teóricos de la traducción, Gredos, Madrid, 1971.

MOUNIN, G., Claves para la semántica, Anagrama, Barcelona, 1975.

OGDEN, C. e I. A. Richards, El significado del significado, Paidós, Buenos Aires, 1964.

OLLER, J. W., «Transformational theory and pragmatics», MLJ, 54 (1970), pp. 504-507.

POTTIER, B., Lingüística moderna y filología hispánica, Gredos, Madrid, 1968.

POTTIER, B., Presentación de la lingüística, Alcalá, Madrid, 1968.

POTTIER, B., Lingüística general, Gredos, Madrid, 1977.

POTTIER, B., «Rehabilitación de la Semántica» apud AAVV, Estructuralismo, pp. 187 192.

PRIETO, L. J., «Langue et style», LL, 1 (1969), pp. 5-24.

REIS, C., Fundamentos y técnicas del análisis literario, Gredos, Madrid, 1981.

RESTREPO, F., Diseño de semántica general, Norma, Colombia, 1938.

REY-DEBOVE, J., «Notes sus une interprétation antonymique de la littérarité: le mode du 'comme je dis'», Li, 4 (1971), pp. 90-95.

RIFFATERRE, M., Ensayos de estilística estructural, Seix Barral, Barcelona, 1976.

ROBINS, R. H., Lingüística general, Gredos, Madrid, 1964.

SANTERRE, R., Introducción al estructuralismo, Nueva Visión, Buenos Aires, 1969.

SCHAFF, A., Lenguaje y conocimiento, Grijalbo, México, 1967.

SCHLIEBEN-LANGE, B., Pragmática, Gredos, Madrid, 1987.

SCHMIDT, S. J., Teoría del texto. Problemas de una lingüística de la comunicación verbal, Cátedra, Madrid, 1978.

SCHÖN, J., «Fonction expresive, redundance et arbitrarieté du signe», LL, 10 (1974), pp. 106 y ss.

SEGOVIA, T., El lenguaje, problemas y reflexiones actuales, Universidad Autónoma de Puebla, México, 1980.

TODOROV, T., «Las categorías del relato literario» apud BARTHES, R., Análisis, pp. $155-$ 193.

TRAPERO, M., El campo semántico 'deporte', Publicaciones de la Caja de Ahorros de Santa Cruz de Tenerife, Santa Cruz, 1979.

TRIVES, E. R., Aspectos de semántica lingüístico-textual, Itsmo-Alcalá, Madrid, 1979.

TRUJILLO, R., El campo semántico de la valoración intelectual en español, Universidad de La Laguna, La Laguna, 1970.

ULLMANN, S., Semántica: introducción a la ciencia del significado, Aguilar, Madrid, 1967. 
ULLMANN, S., Lenguaje y estilo, Aguilar, Madrid, 1968.

URBAN, M., Lenguaje y realidad, Paidós, Buenos Aires, 1952.

WELLEK, R., Historia de la crítica moderna, Gredos, Madrid, 1969.

WÜNDERLICH, D., Pragmatik Sprechsituation, Deixis, Universidad Stuttgart LehrstLinguistik Papier $\mathrm{n}^{\circ}$ 9, 1968.

ZGUSTA, L, Manual of Lexicography, Academia-Mouton, Praga-La Haya-París, 1971. 